\title{
Control of Sugarcane Smut Disease Incited by Sporisorium scitamineum Syd. Using Peroxyacetic Acid (PAA)
}

\section{Galal, A.A}

Plant Pathology Department, Faculty of Agriculture, Minia University, Minia, Egypt.

\begin{abstract}
n eco-friendly agent, hydrogen peroxide $\left(\mathrm{H}_{2} \mathrm{O}_{2}\right)$-based $A$ compound, peroxyacetic acid (PAA) gave efficiency against Sporisorium scitamineum teliospore viability. A significant sporocidal effects for all AA $+\mathrm{H}_{2} \mathrm{O}_{2}$ combinations tested against $S$. scitamineum teliospores germination was explored. The highest inhibitory effect (69.9\% inhibition) was exhibited at $0.2 \mathrm{AA}+4.0 \mathrm{H}_{2} \mathrm{O}_{2} \mathrm{~g} / \mathrm{L}$ followed by $0.1 \mathrm{AA}+4.0 \mathrm{H}_{2} \mathrm{O}_{2} \mathrm{~g} / \mathrm{L}\left(51.9 \%\right.$ inhibition) and $0.2 \mathrm{AA}+2.0 \mathrm{H}_{2} \mathrm{O}_{2}$ $\mathrm{g} / \mathrm{L}$ (48.9\% inhibition).

Under field experiments, most of $\mathrm{AA}+\mathrm{H}_{2} \mathrm{O}_{2}$ treatments were reduced smut disease incidence (SDI) significantly. However, SDI values showed insignificant variances among four treatments, $0.1 \mathrm{AA}+1.0$ $\mathrm{H}_{2} \mathrm{O}_{2} \mathrm{~g} / \mathrm{L}, 0.1 \mathrm{AA}+2.0 \mathrm{H}_{2} \mathrm{O}_{2} \mathrm{~g} / \mathrm{L}, 0.1 \mathrm{AA}+4.0 \mathrm{H}_{2} \mathrm{O}_{2} \mathrm{~g} / \mathrm{L}$ and $0.2 \mathrm{AA}$ $+1.0 \mathrm{H}_{2} \mathrm{O}_{2} \mathrm{~g} / \mathrm{L}$, in two planting dates. While the two treatments, viz. $0.2 \mathrm{AA}+2.0 \mathrm{H}_{2} \mathrm{O}_{2} \mathrm{~g} / \mathrm{L}$ and $0.2 \mathrm{AA}+4.0 \mathrm{H}_{2} \mathrm{O}_{2} \mathrm{~g} / \mathrm{L}$, showed significant variances values in SDI as they significantly reduced SDI values in May more than in October. Meantime, means of protection values (MPV) of $0.2 \mathrm{AA}+2.0 \mathrm{H}_{2} \mathrm{O}_{2} \mathrm{~g} / \mathrm{L}$ and $0.2 \mathrm{AA}+4.0 \mathrm{H}_{2} \mathrm{O}_{2} \mathrm{~g} / \mathrm{L}$, showed significant variances in MPV values as they were significantly raised in May being $86.55 \%$ MPV more than in October, $70.85 \%$ MPV. In May planting date, MPV was significantly higher than in October planting date particularly in the check plants.
\end{abstract}

Keywords: Peroxyacetic acid, $\mathrm{H}_{2} \mathrm{O}_{2}$-based compound, Eco-friendly agent, sugarcane smut, Sporisorium scitamineum.

Sugarcane (Saccharium officinarium L.) is not only a cash crop for the growers, but it is also the main source of white crystal sugar. It is grown in Upper Egypt for sugar production as well as used in the industrial fermentation that necessary for the alcohol, active yeast (bread yeast), citric acid, acetic acid and dextrin (Abd El Fattah, 1996). Of 240 diseases attacked sugarcane plants (Rottet al., 2000), smut is a major disease of sugarcane caused by Sporisorium scitamineum= Ustilago scitaminea (Sydow, 1924). The disease spread is worldwide covering most of the sugarcane producing areas. The wide spread of this disease prompted a great deal of experimental work on it (Heinz, 1987; Akalach, 1994 and Banihashemi, 1995). Lovick (1978) comprehensively reviewed on various aspects of sugarcane smut viz. 
symptoms, yield reduction, causal organism, and physiological races of the smut fungus, epidemiology, host resistance and management. It was reported that severe smut outbreak in the Caribbean has created an impact amongst cane growers and sugar industry. Consequently, the plantations are undertaking different smut management practices such as continued monitoring and rouging of smut affected stools, hot water treatment (at $50^{\circ} \mathrm{C}$ for 2 hours for initial seed cane nursery) of seed sets, chemical treatment of sets, use of resistant varieties, and avoidance of ratooning of affected fields (Abdou et al., 1990; Wada et al., 1999; Abera et al., 2009; Firehunet al., 2009; Mansour et al., 2016; Carvalho et al., 2016; Sánchez-Elordi et al., 2016 and Liu et al., 2017)

Due to their core role in plant health, reactive oxygen species (ROS) and antioxidants Sutherland (1991) and Levine et al. (1994) have shown a major role in plant pathogen interactions (Galal and Abdou, 1996; Adam et al., 2000; Galal, 2017 and EL-Ashmony et al., 2017). Both acetic acid and hydrogen peroxide reacted as bactericides and fungicides against many phytopathogenic bacteria and fungi (Narcisoet al., 2007 and Osórioet al., 2013; Ayoub et al., 2017 and Galal, 2017).

The present study was planned to test the efficacy of $\mathrm{H}_{2} \mathrm{O}_{2}$-based compound PAA on S. scitamineum infectivity either to sugarcane plants at two planting dates during two growing seasons of 2016/2017 and 2017/2018.

\section{Materials and Methods}

\section{Teliospores:}

Teliospores of the pathogen Sporisorium scitamineum Syd. and plants of Saccharum officinarum L., field grown in Mallawy county, Minia governorate, Egypt were used throughout this work. Sugarcane genotype C9 that is commonly cultivated at Minia governorate regions was used in the assays in order to monitor its responses to smut disease.

\section{Pathogenicity tests:}

For pathogenicity tests, teliospores of S. scitamineum, collected from an infected field of cv. C9 (susceptible to smut) were sterilized and incubated as previously described by Santiago et al. (2010). One node-cuttings of sugarcane were surface disinfected using $0.5 \%$ sodium hypochlorite for $5 \mathrm{mn}$ then washed thoroughly by sterilized distilled water then inoculated by paste teliospore (Olweny et al., 2008). Inoculum and inoculation were conducted by suspend teleospores $(65 \%$ viable spores) in $0.8 \%$ soluble starch solution after melting it and cooled, became semi solid (jelly like), before adding teleospores to obtain $10^{5}$ spores $/ \mathrm{ml}$. The waxy layer covered buds was removed gently then buds were inoculated by panting them with about 50uL spore paste then air dried under ambient temperature for $2 \mathrm{~h}$. Forty artificially inoculated cuttings were planted at $1^{\text {st }}$ of May 2015 in one plot $3 \times 3 \mathrm{~m}$ (3 rows/plot) with $2 \mathrm{~m}$ length and $70 \mathrm{~cm}$ width. New whip formed in pathogenicity test

Egypt. J. Phytopathol., Vol. 46, No. 2 (2018) 
was used as a source of inoculation for the subsequent experiments. However, fresh whips formed in check plants of the previous experiment were used as a source of inoculation for subsequent experiments along four planting dates of two years (two planting dates per year).

\section{Preparation of test solutions:}

Six mixtures of acetic acid (AA) and hydrogen peroxide $\left(\mathrm{H}_{2} \mathrm{O}_{2}\right), 0.1 \mathrm{AA}+1.0$ $\mathrm{H}_{2} \mathrm{O}_{2} \mathrm{~g} / \mathrm{L}, 0.1 \mathrm{AA}+2.0 \mathrm{H}_{2} \mathrm{O}_{2} \mathrm{~g} / \mathrm{L}, 0.1 \mathrm{AA}+4.0 \mathrm{H}_{2} \mathrm{O}_{2} \mathrm{~g} / \mathrm{L}, 0.2 \mathrm{AA}+1.0 \mathrm{H}_{2} \mathrm{O}_{2} \mathrm{~g} / \mathrm{L}$, $0.2 \mathrm{AA}+2.0 \mathrm{H}_{2} \mathrm{O}_{2} \mathrm{~g} / \mathrm{L}$ and $0.2 \mathrm{AA}+4.0 \mathrm{H}_{2} \mathrm{O}_{2} \mathrm{~g} / \mathrm{L}$, were prepared with distilled water then left for at least 10 days before the test (Buschmann and Del Negro, 2012 and Anonymous, 2012).

\section{Effect of PAA on teliospores germination:}

Teliospore germination of sugarcane smut fungus $S$. scitamineum was evaluated after $12 \mathrm{~h}$ incubation at $25^{\circ} \mathrm{C}$ onto sterilized water agar plates supplemented by the tested solutions as described before (El-Ashmony et al., 2017), check plates contained unamended water agar.

\section{Field experiments:}

Field experiments were conducted at two planting dates, May and October, during two growing seasons 2016/2017 and 2017/2018 on the field of Plant Pathology Dept., Faculty of Agriculture, Minia University, Minia governorate, Egypt. The attempts were made to evaluate the effect of different combinations of $\mathrm{AA}+\mathrm{H}_{2} \mathrm{O}_{2}$ as cuttings wetting on the disease incidence (SDI) of sugarcane smut considering the effect of SDI on percent disease control (protection \%). The experiments were laid out in randomized complete design with three replications and seven treatments. One-node cuttings of sugarcane cultivar C9 were used throughout this study. Each replicate was one plot $3 \times 3 \mathrm{~m}$ (3 rows/plot) with $2 \mathrm{~m}$ length and 70 $\mathrm{cm}$ width. Cuttings were sown at $20 \mathrm{~cm}$ distance at rate of 10 plants/row and 30 plants/plot. Inoculum and inoculation of sugarcane cuttings were conducted as described in the pathogenicity trail and cuttings were treated by the prepared concentrations of $\mathrm{AA}+\mathrm{H}_{2} \mathrm{O}_{2} 2 \mathrm{~h}$ post inoculation then planted two hours later. All the recommended agronomical practices were adopted for raising the crops.

Disease assessment:

Sugarcane smut incidence (SDI) was monitored 6 months after sowing (Firehun et al., 2009).

\section{Statistical analysis:}

The least significant difference (LSD) at $\mathrm{P}=0.05$ for SDI values of all treatments along two growing seasons per each sowing date individually was calculated (Gomez and Gomez, 1994). 


\section{Results}

1. Effect of PAA on S. scitamineum teliospores germination:

Obvious significant inhibitory effects for all AA + $\mathrm{H} 2 \mathrm{O} 2$ combinations tested were explored against teliospores germination (Table 1). Increasing AA or $\mathrm{H}_{2} \mathrm{O}_{2}$ increased teliospores germination inhibition. Lowest inhibitory effect $(18.9 \%$ inhibition) was provided at $0.1 \mathrm{AA}+1.0 \mathrm{H}_{2} \mathrm{O}_{2} \mathrm{~g} / \mathrm{L}$ followed by $0.1 \mathrm{AA}+2.0 \mathrm{H}_{2} \mathrm{O}_{2}$ $\mathrm{g} / \mathrm{L}$ that caused 21.95 inhibition. The highest inhibitory effect $(69.9 \%$ inhibition) was exhibited at $0.2 \mathrm{AA}+4.0 \mathrm{H}_{2} \mathrm{O}_{2} \mathrm{~g} / \mathrm{L}$ while using $0.1 \mathrm{AA}+4.0 \mathrm{H}_{2} \mathrm{O}_{2} \mathrm{~g} / \mathrm{L}$ expressed 51.9\%inhibition. Meanwhile, insignificant difference was recorded with using $0.2 \mathrm{AA}+2.0 \mathrm{H}_{2} \mathrm{O}_{2} \mathrm{~g} / \mathrm{L}$ which explored $48.9 \%$ inhibition.

Table 1: Germination\% of Sporisorium scitamineum teliospores as affected by various combinations of acetic acid $(\mathrm{AA})+$ hydrogen peroxide $\left(\mathrm{H}_{2} \mathrm{O}_{2}\right)$ incubated at $25^{\circ} \mathrm{C}$ for $12 \mathrm{hr}$.

\begin{tabular}{|c|c|c|}
\hline Treatments and Conc. $(\mathrm{g} / \mathrm{l})$ & Germination \% & Inhibition \% \\
\hline Untreated & $66.6 \mathrm{a}$ & 0.00 \\
$\mathrm{AA}+\mathrm{H}_{2} \mathrm{O}_{2}$ & & \\
$0.1+1.0$ & $54 \mathrm{ab}$ & 18.90 \\
$0.1+2.0$ & $42 \mathrm{c}$ & 21.95 \\
$0.1+4.0$ & $34 \mathrm{~d}$ & 51.90 \\
$0.2+1.0$ & $48 \mathrm{~b}$ & 27.90 \\
$0.2+2.0$ & $36 \mathrm{~d}$ & 48.90 \\
$0.2+4.0$ & $22 \mathrm{e}$ & 69.90 \\
\hline
\end{tabular}

Values with the same letters are not significantly differed

\section{Effect of PAA on sugarcane smut incidence (SDI) under field experiments:}

\subsection{May planting date:}

Along two growing seasons for May planting date, all treatments (except 0.1 AA $+1.0 \mathrm{H}_{2} \mathrm{O}_{2} \mathrm{~g} / \mathrm{L}$ ) showed significant protection values against smut infection as compared to untreated inoculated sugarcane cuttings (Table 2). Increasing AA or $\mathrm{H}_{2} \mathrm{O}_{2}$ resulted in protection enhancement. The highest protection value $(86.55 \%)$ was obtained by using $0.2 \mathrm{AA}+4.0 \mathrm{H}_{2} \mathrm{O}_{2} \mathrm{~g} / \mathrm{L}$ followed by $0.2 \mathrm{AA}+2.0 \mathrm{H}_{2} \mathrm{O}_{2} \mathrm{~g} / \mathrm{L}$ which caused $60.61 \%$ protection. The least $0.1 \mathrm{AA}+1.0 \mathrm{H}_{2} \mathrm{O}_{2} \mathrm{~g} / \mathrm{L}$ combination showed insignificant SDI reduction (5.59\%) of protection while using $0.1 \mathrm{AA}+2.0$ $\mathrm{H}_{2} \mathrm{O}_{2} \mathrm{~g} / \mathrm{L}$ caused $27.69 \%$ protection. At $0.2 \mathrm{AA}+1.0 \mathrm{H}_{2} \mathrm{O}_{2} \mathrm{~g} / \mathrm{L}$, SDI was significantly decreased, recording $37.58 \%$ protection while $0.1 \mathrm{AA}+4.0 \mathrm{H}_{2} \mathrm{O}_{2} \mathrm{~g} / \mathrm{L}$ exhibited $42.80 \%$ protection. Untreated inoculated sugarcane cuttings resulted in SDI at May 2016 higher than May 2017 as well as treatments were most effective by May 2016 than May 2017.

Egypt. J. Phytopathol., Vol. 46, No. 2 (2018) 
Table 2: Sugarcane smut incidence (SDI) as influenced by treatment of post inoculated sugarcane cuttings cv., $\mathrm{C} 9$ with the tested solutions of various acetic acid (AA) and hydrogen peroxide $\left(\mathrm{H}_{2} \mathrm{O}_{2}\right)$ combinations. Smut incidence was monitored six months after planting in May $1^{\text {st }}$ of 2016 and 2017.

\begin{tabular}{|c|c|c|c|c|}
\hline $\begin{array}{c}\text { Treatments and Conc. } \\
(\mathrm{g} / \mathrm{l})\end{array}$ & \multicolumn{2}{|c|}{ Smut incidence during } & \multirow{2}{*}{ Mean } & $\begin{array}{c}\text { Protection } \\
\%\end{array}$ \\
\cline { 2 - 3 } & 2016 & 2017 & & 0.00 \\
$\mathrm{AA}+\mathrm{H}_{2} \mathrm{O}_{2}$ & 58.7 & 52.5 & 55.6 & \\
$0.1+1.0$ & & & 51.5 & 5.59 \\
$0.1+2.0$ & 53.4 & 49.7 & 40.2 & 27.69 \\
$0.1+4.0$ & 41.8 & 38.6 & 32.3 & 42.80 \\
$0.2+1.0$ & 32.7 & 31.8 & 34.7 & 37.58 \\
$0.2+2.0$ & 24.2 & 33.2 & 21.9 & 60.61 \\
$0.2+4.0$ & 5.4 & 9.6 & 7.5 & 86.55 \\
\hline Mean & 36.1 & 33.6 & 35.0 & \\
\hline LSD at 0.05 for Treatments (A) 4.8, Growing seasons (B) $3.6, \mathrm{~A} \times \mathrm{B} 7.8$ \\
\hline
\end{tabular}

\subsection{October planting date:}

Generally, all treatments showed significant SDI reduction at October planting date even at the lowest concentration, $0.1 \mathrm{AA}+1.0 \mathrm{H}_{2} \mathrm{O}_{2} \mathrm{~g} / \mathrm{L}$, which caused $10.85 \%$ protection (Table 3). Increasing $\mathrm{AA}$ or $\mathrm{H}_{2} \mathrm{O}_{2}$ enhanced protection where $0.2 \mathrm{AA}+$ $4.0 \mathrm{H}_{2} \mathrm{O}_{2} \mathrm{~g} / \mathrm{L}$ combination expressed the highest protection value $(70.80 \%$ protection) followed by $0.2 \mathrm{AA}+2.0 \mathrm{H}_{2} \mathrm{O}_{2} \mathrm{~g} / \mathrm{L}$ that provided $52.8 \%$ protection and $0.1 \mathrm{AA}+4.0 \mathrm{H}_{2} \mathrm{O}_{2} \mathrm{~g} / \mathrm{L}$ which showed $41.96 \%$ protection.

Table 3: Sugarcane smut incidence (SDI) as influenced by treatment of post inoculated sugarcane cuttings cv, C9 with the tested solutions of various acetic acid (AA) and hydrogen peroxide $\left(\mathrm{H}_{2} \mathrm{O}_{2}\right)$ combinations. Smut incidence was monitored six months after planting in October $1^{\text {st }}$ of 2016 and 2017.

\begin{tabular}{|c|c|c|c|c|}
\hline \multirow{2}{*}{$\begin{array}{c}\text { Treatments and } \\
\text { Conc. }(\mathrm{g} / \mathrm{l})\end{array}$} & \multicolumn{2}{|c|}{ Smut incidence during } & \multirow{2}{*}{ Mean } & $\begin{array}{c}\text { Protection } \\
\%\end{array}$ \\
\cline { 2 - 3 } & 2016 & 2017 & 45.9 & 0.00 \\
$\mathrm{~A}$ Untreated $+\mathrm{H}_{2} \mathrm{O}_{2}$ & 48.3 & 43.6 & 39.9 & 10.85 \\
$0.1+1.0$ & 38.4 & 41.4 & 36.4 & 20.69 \\
$0.1+2.0$ & 36.5 & 36.3 & 26.7 & 41.96 \\
$0.1+4.0$ & 31.3 & 22.2 & 31.05 & 32.45 \\
$0.2+1.0$ & 28.8 & 33.3 & 22.5 & 52.8 \\
$0.2+2.0$ & 23.6 & 21.4 & 13.15 & 70.80 \\
$0.2+4.0$ & 13.7 & 12.6 & 30.7 & \\
Mean & 31.5 & 30.1 & \multicolumn{3}{|c|}{ Egypt. J. Phytopathol., Vol. 46, No. 2(2018) }
\end{tabular}




\subsection{Comparison between planting dates:}

Generally, SDI in May planting date was significantly higher than that in October planting date particularly in check plants (control) as shown in Table (4), as the check plants showed mean values of SDI $55.6 \%$ by May planting date compared to $45.9 \%$ in October planting date. However, SDI values showed insignificant differences among four treatments, $0.1 \mathrm{AA}+1.0 \mathrm{H}_{2} \mathrm{O}_{2} \mathrm{~g} / \mathrm{L}, 0.1 \mathrm{AA}+2.0 \mathrm{H}_{2} \mathrm{O}_{2} \mathrm{~g} / \mathrm{L}$, $0.1 \mathrm{AA}+4.0 \mathrm{H}_{2} \mathrm{O}_{2} \mathrm{~g} / \mathrm{L}$ and $0.2 \mathrm{AA}+1.0 \mathrm{H}_{2} \mathrm{O}_{2} \mathrm{~g} / \mathrm{L}$, during the two planting dates. While the two treatments, viz. $0.2 \mathrm{AA}+2.0 \mathrm{H}_{2} \mathrm{O}_{2} \mathrm{~g} / \mathrm{L}$ and $0.2 \mathrm{AA}+4.0 \mathrm{H}_{2} \mathrm{O}_{2} \mathrm{~g} / \mathrm{L}$, showed significant differences in SDI values, since they significantly decreased SDI values in May more than in October. Meantime, means of protection values (MPV) of $0.2 \mathrm{AA}+2.0 \mathrm{H}_{2} \mathrm{O}_{2} \mathrm{~g} / \mathrm{L}$ and $0.2 \mathrm{AA}+4.0 \mathrm{H}_{2} \mathrm{O}_{2} \mathrm{~g} / \mathrm{L}$, showed significant differences since they significantly rised MPV values in May (86.55\% MPV more than in October (70.*\%MPV).

Table 4: Comparison between May and October sowing dates means values of smut incidence (SDI) and protection (MPV) as influenced by treatment of post inoculated sugarcane cuttings cv, $\mathrm{C} 9$ with the test solutions of various acetic acid (AA) and hydrogen peroxide $\left(\mathrm{H}_{2} \mathrm{O}_{2}\right)$ combinations.

\begin{tabular}{|c|c|c|c|c|}
\hline \multirow{2}{*}{$\begin{array}{c}\text { Treatments and Conc. } \\
(\mathrm{g} / \mathrm{l})\end{array}$} & \multicolumn{2}{|c|}{$\begin{array}{c}\text { Means of SDI for } \\
\text { Plating date (Mean } \\
\text { Values of two seasons) }\end{array}$} & \multicolumn{2}{|c|}{ MPV of planting date, } \\
\cline { 2 - 5 } & May & October & May & October \\
\hline Untreated & $55.6 \mathrm{a}$ & $45.9 \mathrm{~b}$ & $0.0 \mathrm{~g}$ & $0.0 \mathrm{~g}$ \\
$\mathrm{AA}+\mathrm{H}_{2} \mathrm{O}_{2}$ & & & & \\
$0.1+1.0$ & $51.5 \mathrm{a}$ & $39.4 \mathrm{c}$ & $5.59 \mathrm{~g}$ & $10.85 \mathrm{f}$ \\
$0.1+2.0$ & $40.2 \mathrm{c}$ & $36.4 \mathrm{~cd}$ & $27.69 \mathrm{e}$ & $20.69 \mathrm{e}$ \\
$0.1+4.0$ & $32.3 \mathrm{~d}$ & $26.7 \mathrm{e}$ & $42.80 \mathrm{c}$ & $41.96 \mathrm{c}$ \\
$0.2+1.0$ & $34.7 \mathrm{~cd}$ & $31.1 \mathrm{~d}$ & $37.58 \mathrm{~d}$ & $32.45 \mathrm{~d}$ \\
$0.2+2.0$ & $21.9 \mathrm{e}$ & $22.5 \mathrm{e}$ & $60.61 \mathrm{c}$ & $52.8 \mathrm{~d}$ \\
$0.2+4.0$ & $7.5 \mathrm{f}$ & $13.15 \mathrm{f}$ & $86.55 \mathrm{a}$ & $70.80 \mathrm{~b}$ \\
\hline
\end{tabular}

Values with the same letters are not significantly differed

\section{Discus sion}

Sugarcane smut continues to be a serious threat to sugarcane production in different countries. Integrated disease management strategy is the viable option in smut disease control, rather than resorting to a single method. Recommended phytosanitary practices like seed selection, roguing of infected clumps etc is the best possible way to reduce smut inoculum levels (Sundar et al., 2012). The current work showed a significant sporocidal effects for all AA $+\mathrm{H}_{2} \mathrm{O}_{2}$ combinations tested against $S$. scitamineum teliospores germination. The highest inhibitory effect $(69.9 \%$ inhibition) was exhibited at $0.2 \mathrm{AA}+4.0 \mathrm{H}_{2} \mathrm{O}_{2} \mathrm{~g} / \mathrm{L}$ while using $0.1 \mathrm{AA}+4.0 \mathrm{H}_{2} \mathrm{O}_{2}$ 
$\mathrm{g} / \mathrm{L}$ expressed 51.9\%inhibition that showed insignificant effect with using $0.2 \mathrm{AA}+$ $2.0 \mathrm{H}_{2} \mathrm{O}_{2} \mathrm{~g} / \mathrm{L}$ which explored $48.9 \%$ inhibition. Antifungal effects for PAA which resulted from mixed AA $+\mathrm{H}_{2} \mathrm{O}_{2}$ (Buschmann and Del Negro, 2012) were confirmed against several phytopathogenic fungi ((Mari et al., 2004; Feliziani et al., 2016; Ayoub et al., 2017 and El-Ashmony et al., 2017).

In plants, reactive oxygen species (ROS) play a crucial role in growth, development and in plant defense against the pathogens (Foreman et al., 2003 and Kawano, 2003). For example there are at least 152 genes involved in ROS secretion, function and signaling in Arabidopsis thaliana (Mittler et al., 2004). During plant pathogen interactions, ROS function in the formation of physical defense components (such as cell wall appositions) and in the activation of the $\mathrm{R}$ genemediated cell wall appositions (Delledonne et al., 2001 and Collinge, 2009). The recent study for May planting date explored that all treatments (except $0.1 \mathrm{AA}+1.0$ $\mathrm{H}_{2} \mathrm{O}_{2} \mathrm{~g} / \mathrm{L}$ ) showed significant protection values against smut infection as compared to untreated inoculated sugar cane cuttings. The highest protection value $(86.55 \%$ protection) was pronounced by using $0.2 \mathrm{AA}+4.0 \mathrm{H}_{2} \mathrm{O}_{2} \mathrm{~g} / \mathrm{L}$ followed by $0.2 \mathrm{AA}+$ $2.0 \mathrm{H}_{2} \mathrm{O}_{2} \mathrm{~g} / \mathrm{L}$ which caused $60.61 \%$ protection. The least $0.1 \mathrm{AA}+1.0 \mathrm{H}_{2} \mathrm{O}_{2} \mathrm{~g} / \mathrm{L}$ combination showed insignificant SDI reduction, $5.59 \%$ protection. Untreated inoculated sugarcane cuttings resulted in SDI at May 2016 higher than May 2017 as well as treatments were most effective by May 2016 than May 2017. By October planting date, all treatments showed significant SDI reduction even at the lowest concentration, $0.1 \mathrm{AA}+1.0 \mathrm{H}_{2} \mathrm{O}_{2} \mathrm{~g} / \mathrm{L}$, which caused $10.85 \%$ protection. The highest protection value (70.80\% protection) was caused by $0.2 \mathrm{AA}+4.0 \mathrm{H}_{2} \mathrm{O}_{2} \mathrm{~g} / \mathrm{L}$ followed by $0.2 \mathrm{AA}+2.0 \mathrm{H}_{2} \mathrm{O}_{2} \mathrm{~g} / \mathrm{L}$ that provided $52.8 \%$ protection and $0.1 \mathrm{AA}+$ $4.0 \mathrm{H}_{2} \mathrm{O}_{2} \mathrm{~g} / \mathrm{L}$ which showed $41.96 \%$ protection.

Generally, SDI in May planting date was significantly higher than in October planting date particularly in check plants (control), as check plants showed mean values of SDI $55.6 \%$ by May planting date and $45.9 \%$ in October planting date. However, SDI values showed insignificant differences among the four treatments, $0.1 \mathrm{AA}+1.0 \mathrm{H}_{2} \mathrm{O}_{2} \mathrm{~g} / \mathrm{L}, 0.1 \mathrm{AA}+2.0 \mathrm{H}_{2} \mathrm{O}_{2} \mathrm{~g} / \mathrm{L}, 0.1 \mathrm{AA}+4.0 \mathrm{H}_{2} \mathrm{O}_{2} \mathrm{~g} / \mathrm{L}$ and $0.2 \mathrm{AA}$ $+1.0 \mathrm{H}_{2} \mathrm{O}_{2} \mathrm{~g} / \mathrm{L}$, during the two planting dates. While the two treatments, viz. 0.2 AA $+2.0 \mathrm{H}_{2} \mathrm{O}_{2} \mathrm{~g} / \mathrm{L}$ and $0.2 \mathrm{AA}+4.0 \mathrm{H}_{2} \mathrm{O}_{2} \mathrm{~g} / \mathrm{L}$, showed significant variances in SDI values, since they significantly decreased SDI values in May more than in October. Meantime, means of protection values (MPV) of $0.2 \mathrm{AA}+2.0 \mathrm{H}_{2} \mathrm{O}_{2} \mathrm{~g} / \mathrm{L}$ and 0.2 $\mathrm{AA}+4.0 \mathrm{H}_{2} \mathrm{O}_{2} \mathrm{~g} / \mathrm{L}$, showed significant variances in MPV values, since they significantly raised MPV values in May $(86.55 \%$ MPV more than in October (70.85\% MPV). Condition(s) are critically important in the development and spread of the pathogen causing smut of sugarcane. Some of these can be utilized to form the basis of disease prediction model. They may vary in their combinations in different agro climatic zones and influence not only the pathogen but also the host (Mansoor et al., 2016). Narciso et al. (2007) reported that sensitivity of Botrytis cinerea hyphae and conidia to PAA was shown by the presence of a zone of inhibition using 
the disc assay method. Galal (2017) recommended PAA for integrated disease management program (IDM) against powdery mildew of okra and sunflower plants. Application of PAA against several plant diseases caused by either phytopathogenic fungi (Hopkins et al., 2003; Mari et al., 2004; Pukdee and Sardsud, 2007; Thipaksorn et al., 2012; Feliziani et al., 2016 and Ayoub et al., 2017; Galal, 2017 and El-shmony et al., 2017) or phytopathogenic bacteria (Hopkins et al., 2009 and Hong et al., 2018). The results of this work confirm the findings recorded by Galal (2017) on okra and sunflower powdery mildew and can be included in an integrated disease management programs for sugarcane smut.

\section{References}

Abdel-Fattah, A.I. 1996. Studies on sugarcane mosaic virus disease in Egypt. M. Sc. Thesis, Fac. Agric. Zagazig Univ., Zagazig, Egypt, pp 95.

Abdou, Y.A.; Moursy, M.A.; AbdeI-Fattah, M.N.D. and Mansour, I.M. 1990. Effect of temperature and certain cultural practices on longevity of teliospores of Ustilagoscitaminea. Bulletin of the Faculty of Agriculture, University of Cairo, 41 (12): 491 - 510.

Abera, T.; Firehun, Y. and Solomon, B. 2009. Review of sugarcane protection research in Ethiopia. P.p. 409-447. In: Abraham T. (ed.) Increasing crop production through improved plant protection: Vol. 2. Plant Protection Society of Ethiopia, Addis Ababa, Ethiopia. Importance and Status of Sugarcane Smut 46].

Adam, A.L.; Galal, A.A.; Manninger, K. and Barna, B. 2000. Inhibition of the development of leaf rust (Puccinia recondita) by treatment of wheat with allopurinol and production of a hypersensitive-like reaction in a compatible host. Plant Pathology, 49(3): 317-323.

Akalach, M. 1994. First report of sugarcane smut in Morocco. Plant Disease, 78(5): 529.

Anonymous, 2012. Alternative Disinfection Methods Fact Sheet: Peracetic Acid. US Environmental protection Agency, Office of Wastewater Management (EPA), 832-F-12-030 D.C.

Ayoub, F.; Oujji, N.B.; Chebli, B.; Ayoub, M.; Hafidi, A.; Salghi, R. and Jodeh, S. 2017. Antifungal effectiveness of fungicide and peroxyacetic acid mixture on the growth of Botrytis cinerea. Microbial Pathogenesis, 105: 74-80.

Banihashemi, Z. 1995. The occurrence of sugarcane smut in Mazandarn Province. Iranian Journal of Plant Pathology, 31(1/4):40-41.

Buschmann, W.E. and Del Negro A.S. 2012. Production of peroxycarboxylic acids. USA Patent US8318972B2. 845 November 27.

Egypt. J. Phytopathol., Vol. 46, No. 2 (2018) 
Carvalho, G.; Quecine, M.C.; Longatto, D.P.; Peters, L.P.; Almeida, J.R.; Shyton, T.G.; Silva, M.M.L.; Crestana, G.S.; Creste, S. and Monteiro-Vitorello1, C.B. 2016. Sporisorium scitamineum colonisation of sugarcane genotypes susceptible and resistant to smut revealed by GFP-tagged strains. Ann Appl Biol 169: 329341.

Collinge, D.B. 2009. Cell wall apposition: The first line of defence. J. Exp. Bot., 60: 351-352.

Dellledonne, M.; Zeier, J.; Marocco, A. and Lamb, C. 2001. Signal interactions between nitric oxide and reactive oxygen intermediates in the plant hypersensitive disease reponse. Proc. Nati. Acad. Sci. USA, 98:13454-13459.

El-Ashmony, R.M.S.; Abdel-Latif, M.R.; Abdou, El-S. and Galal, A.A. 2017. Peroxyacetic acid (PAA) an eco-friendly agent for reducing Sclerotinia sclerotiorum growth, sclerotiacarpogenic germination and infectivity. Egypt. J. Phytopathol., 45(2): 67-78.

Feliziani, E.; Lichterb, A.J.; Smilanickc, L. and Ippolitod, A. 2016. Disinfecting agents for controlling fruit and vegetable diseases after harvest. Postharvest Biology and Technology, 122: 53-69.

Firehun, Y.; Abera, T.; Yohannes, Z. and Leul, M. 2009. Handbook for Sugarcane Pest Management in Ethiopia. Ethiopian Sugar Development Agency Research Directorate, Ethiopia,

Foreman, J.; Demidchik, V.; Bothwell, J.H.; Mylona, P.; Miedema, H.; Torres, M. A.; Linstead, P.; Costa, S.; Brownlee, C.; Jones, J. D.; Davis, J. M. and Dolan, L. 2003. Reactive oxygen species produced by NADPH oxidase regulate plant cell growth. Nature, 422:442-446.

Galal, A.A. 2017. Suppression of powdery mildew in okra and sunflower plants under natural infection through peroxyacetic acid foliar application. Egypt. J. Phytopathol., 45(2): 93-102.

Galal, A.A. and Abdou, EL-S. 1996. Antioxidants for the control of fusarial disease in cowpea. Egypt J. Phytopathol., 24: 1-12.

Gomez, K.A. and Gomez, A.A. 1994. Statistical Procedures for Agricultural Research, $2^{\text {nd }}$ edn. New York, USA: John Wiley and Sons. pp 680

Heinz, D.J. 1987. Sugarcane improvement through breeding. Elsevier Publications, pp. 455-502.

Hong, J.K.; Jang, J.S.; Lee, H.Y.; Jo, S.Y.; Yun, G.J.; Park, J. C. and Kim, J.H. 2018. Reduced bacterial wilt in tomato plants by bactericidal peroxyacetic acid mixture treatment. Plant Pathol. J., 34(1):87-84. 
Hopkins, D.L.; Hilgren, J.; Lovic, B. and Thompson, C.M. 2003. Wet seed treatment with peroxyacetic acid for the control of bacterial fruit blotch and other seed borne diseases of watermelon. Plant Disease, 87(12): 1495-1499.

Hopkins, D.L.; Thompson, C.M. and Lovic, B. 2009. Management of transplant house spread of Acidovo raxavenae subsp. citrullion cucurbits with bactericidal chemicals in irrigation water. Plant Health Progress, Website: http://www.plantmanagementnetwork.org/pub/php/research/2009/acidovorax/.

Kawano, T. 2003. Roles of the reactive oxygen species generating peroxidase reactions in plant defense and growth induction. Plant Cell Rep., 21:829-837.

Levine, A.; Tenhaken, R.; Dixon, R. and Lamb, C. 1994. $\mathrm{H}_{2} \mathrm{O}_{2}$ from the oxidative burst orchestrates the plant hypersensitive disease resistance response. Cell, 79: 583-593.

Liu, S.; , Lin, N.; Chen, Y.; Liang, L.; Liao; M.; Lv1, Y.; Chen, Y.; Tang,, F.; He, S.; Chen, J.; Zhou, I. and Zhan, Z. G. 2017. Biocontrol of sugarcane smut disease by interference of fungal sexual mating and hyphal growth using a bacterial isolate. Frontiers in Microbiology | www.frontiersin.org

Lovick, G. 1978. Smut of sugarcane - Ustilago scitaminea. Review of Plant Pathology, 57(5): 181-188.

Mansoor, S.; Khan, M.A. and Khan, N.A .2016. Screening of sugarcane varieties / lines against whip smut disease in relation to epidemiological factors. J Plant Pathol. Microbiol., 7: 366.

Mari, M.; Gregori., R. and Donati, I. 2004. Postharvest control of Monilinialaxa and Rhizopus stolonifer in stone fruit by peracetic acid. Postharvest Biology and Technology, 33: 319-325.

Mittler, R.; Vanderauwera, S.; Gollery, M. and Breusegem, F.V. 2004. Reactive oxygen gene network of plants. Trends Plant Sci., 9: 490-498.

Narciso, J.A.; Baldwin E.A.; Plotto, A. and Ference, C.M. 2007. Preharvest peroxyacetic acid sprays slow decay and extend shelf life of strawberries. Hort. Science, 42(3): 617-621.

Olweny, C.O.; Ngugi, K.; Nzioki, H. and Githri, S.M. 2008. Evaluation of smut inoculation techniques insugarcane seedlings. Sugar Tech., 10: 341-345.

Osorio, G.T.; oliveira, B.S. and R.M. Dipiero. 2013. Effect of fumigants on blue and gray molds of apple fruit. Tropical Plant Pathology, 38(1): 063-067.

Pukdee, S., and Sardsud, U. 2007. Use of acetic acid, peracetic acid and acetate salts for controlling green mold on tangerine cv. Sai Num Phueng. J. Agricultural Science, 38(5) (Suppl.): 193-196.

Egypt. J. Phytopathol., Vol. 46, No. 2 (2018) 
Rott, P.; Bailey, A.; Comstock, J.C. and Croft, B.J. 2000. Whip smut of Sugarcane. A guide to sugarcane diseases. CIRAD and ISSCT Publishing Co. Amsterdam, Netherland pp: 339-341.

Sánchez-Elordi, E; Moralnes de los Ríos, L.; Díaz, E.M.; Ávila, A.; Legaz, M.E. and Vicente, C. 2016. Defevsive glycoproteins from sugarcane plants induce chemotaxis, cytoagglutination and death of smut teliospores. Journal of Plant Pathology, 98(3): 493-501.

Santiago, R.; Quintana, J.; Rodrsguez, S.; Dي̣az, E.M.; Legaz, M.E. and Vicente C. 2010. An elicitor isolated from smut teliospores (Sporisorium scitamineum) enhances lignin deposition on the cell wall of both sclerenchyma and xylem in sugarcane leaves. Pak. J. Bot., 42(4): 2867-2881.

Sutherland, M.W. 1991. The generation of oxygen radical during host plant response to infection. Physiol. Mol. Pl. Pathol., 39: 79-93.

Thipaksorn, C.; Rattanapanone, N. and Boonyakiat, D. 2012. Effects of peroxyacetic acid, peroxycitric acid, sodium bicarbonate, potassium sorbate, and potassium metabisulfite on the control of green moldin Sai Nam Phueng tangerine fruit. CMU. J. Nat. Sci., 11(2): 203-211.

Sundar, A.R.; Leonard Barnabas, P.M. and Viswanathan, R. 2012. A mini-review on smut disease of sugarcane caused by Sporisorium scitamineum A. Ramesh Sundar, E. Leonard Barnabas, P. Malathi and R. Viswanathan. In Botany. John Mworia (ed.) pp 226. InTech, www.intechopen.com

Sydow, H. 1924. Notizen Uber Ushlagineen. Ann. Mycol., 22: 277.

Wada, A.C.; Mian, M.A.W.; Anaso, A.B.; Busaro, I.D. and Kwon-Ndung, 1999. Control of sugarcane smut (Ustilago scitaminea Syd) disease in Nigeria and suggestions for integrated pest management approach. Sugar Tech., 1(3): 48-53.

(Received 16/07/2018;

in revised form 07/08/2018) 


\section{مكافحة مرض تفحم قصب السكر المتسبب عن الإصابة

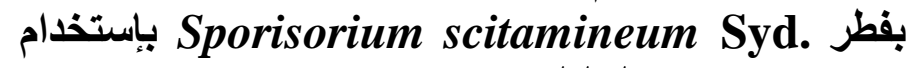 بيروكسي حمض الخليك \\ أنور عبد العزيز جلال}

قسم أمراض النبات ، كلية الزراعة ، جامعة المنيا ، المنيا ، مصر جلر

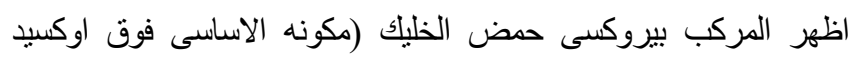

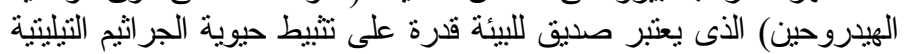

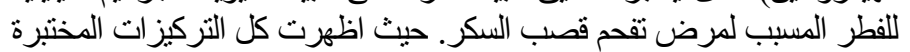

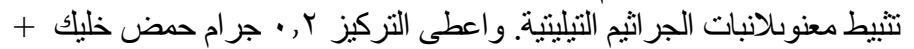

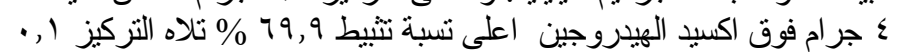

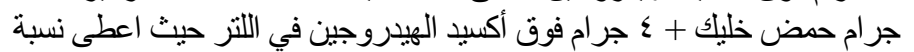

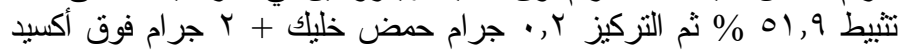

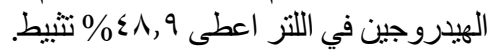

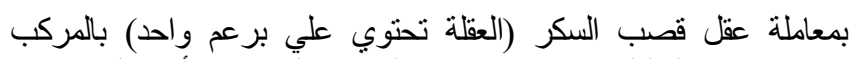

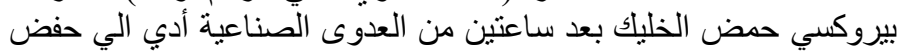

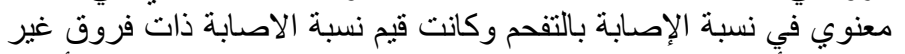

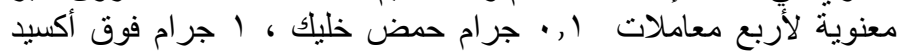

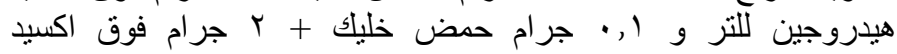

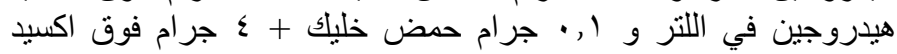

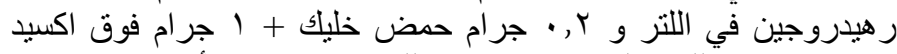

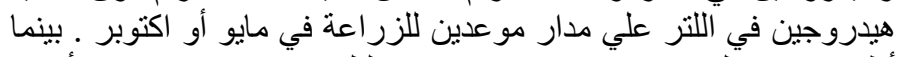

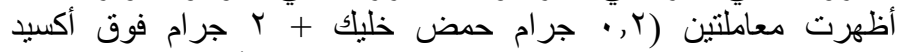

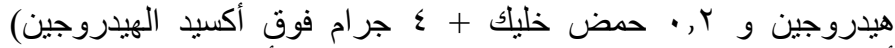

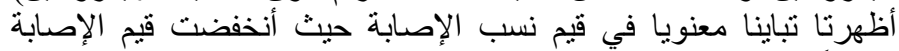

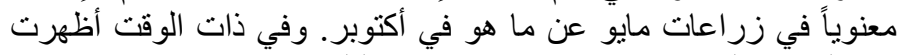

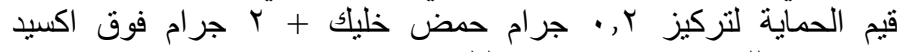

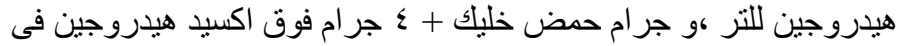

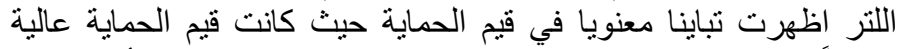

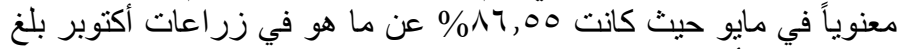

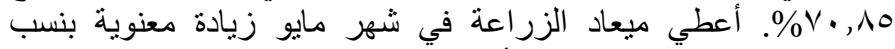
الإصابة بالتفحم مقارنة بشهر أكتوبر خاصة في النبانة فياتات الغير معاملة

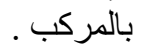

